\title{
Insight Into Firms' Strategy for Leveraging Technological Competences in Asia
}

\author{
V.K. Gupta* \\ National Institute of Science, Technology and Development Studies, New Delhi, India
}

\begin{abstract}
Technological skills of inventors have become important for innovation and competitiveness of firms in the knowledge based industries. With the emerging globalization, firms that make use of technological competence of inventors worldwide innovate and prosper faster. The present study examines how national or foreign firms leverage the technological competence of inventors from Asian and other countries. A related question has also been examined as to how these firms leverage technological competence of inventors exclusively from foreign countries without the involvement of inventors from their own countries. The study presents a methodology for extracting relevant data and analysis of bibliographic information in a patent document to provide insights into firms' innovation strategies, while leveraging technological competences of inventors.

The case study of leveraging technological competence of inventors from India, by foreign or national firms, has been presented in detail to provide policy relevant understanding of the pattern of distribution of assignee firms or other organizations leveraging the competence a) by performing sector viz. industry, university or government, b) by countries of origin of firms, c) the role of key foreign or Indian firms, and d) the technical areas in which technological competence is leveraged. Similar studies could be undertaken in case of other countries, as well to formulate innovation strategy and policy at the national or firm level.
\end{abstract}

\section{INTRODUCTION}

The globalization has affected the process of innovation, generation and transmission of scientific and technological knowledge, wherein new inventions, technologies and products are produced and used within the borders of a national state, on the one hand, and are exploited internationally and transmitted across countries, on the other hand. These processes have introduced an increased competition in the national economy, wherein the national firms and organisations have to compete in terms of cost and quality of products as well as in accessing advanced technological skills and critical human resources. A shift is taking place in innovative activities towards "knowledge-based" industries such as chemicals and pharmaceuticals, electronics, information technology, software, nanotechnology, and biotechnology. A characteristic of several of these industries is an enormous gap between the cost of discovering or developing a new innovation and the ease with which innovations can be copied. The R\&D environment, for firms engaged in such areas, is characterized by the high innovation risks, high investments in research and development, and scarcity of highly skilled human resources. The technological skill of inventors engaged in $R \& D$ and creating new products, processes or patentable inventions has, particularly, become significant for firms to innovate.

\section{SCOPE AND OBJECTIVES}

In the face of rapid technological change, maintaining a competitive edge requires firms to look for technological

\footnotetext{
"Address correspondence to this author at the National Institute of Science, Technology, Development Studies, New Delhi, India; Tel: 9810017402; Fax: 011-25846640; E-mail: vkgdwarka@gmail.com
}

skills outside their home country for augmenting their technological capability. Firms that make use of the technological competence of inventors located worldwide, innovate, prosper and grow faster, while others, who are not able to do so, find it difficult to retain their competitive edge. The changing economic policies and reforms among several Asian economies have reinforced the importance of R\&D policies to focus attention on the emerging issues of technological skills of inventors that conduct R\&D and create patentable inventions. The working of inventors from Asian countries for foreign firms may provide them exposure to upfront inventive activity and enhance technological content of their competences. However, it may preclude their availability to national firms and R\&D organizations, which in turn may affect the endogenous innovative capacity. The policy-makers from Asian countries, particularly, the developing Asian countries, need to understand how technological competences of inventors from their countries are utilized by whom - foreign or national firms and evolve relevant policies so that outsourcing of inventive competence by foreign companies does not adversely affect the endogenous innovative capacity. The objectives of this paper are to examine how domestic or foreign firms are utilizing the technological skills of inventors in generating patentable inventions, from select Asian countries, compare it with some other European and Latin American countries, and provide insights into firms' strategy in leveraging technological competences for patenting. In particular, to provide an understanding of the pattern of leveraging of the technological competence of Indian inventors by foreign or national firms by indicating the distribution of assignees a) by performing sector viz. industry, university or government, b) by countries of origin of firms, c) the key foreign or Indian firms, and d) the technical areas in which technological competence is leveraged. 
Table 1. Search Query and Codes to Obtain Relevant Data Used in Table 2 and Table 3

\begin{tabular}{|c|c|c|c|c|c|}
\hline $\begin{array}{l}\text { Inventor } \\
\text { country }\end{array}$ & $\begin{array}{l}\text { Country } \\
\text { code }\end{array}$ & $\begin{array}{l}\text { Search query to } \\
\text { obtain data on } \\
\text { patents as inventor } \\
\text { country }\end{array}$ & $\begin{array}{l}\text { Search query to obtain data } \\
\text { on patents owned by as- } \\
\text { signees from inventor coun- } \\
\text { try wherein none of the } \\
\text { inventors are from the } \\
\text { inventor country }\end{array}$ & $\begin{array}{l}\text { Search query to obtain data } \\
\text { on patents wherein at least } \\
\text { one inventor is from the } \\
\text { inventor country but owned } \\
\text { by assignees from its foreign } \\
\text { country }\end{array}$ & $\begin{array}{l}\text { Search query to obtain data on } \\
\text { patents wherein at least one } \\
\text { inventor is from the inventor } \\
\text { country and owned by its na- } \\
\text { tional assignees }\end{array}$ \\
\hline Japan & JP & $\begin{array}{l}\text { ICN/JP and } \\
\text { ISD/20010101- } \\
>20013112\end{array}$ & $\begin{array}{l}\text { ACN/JP andnot ICN/JP and } \\
\text { ISD/20010101->20013112 }\end{array}$ & $\begin{array}{l}\text { ICN/JP andnot ACN/JP and } \\
\text { ISD/20010101->20013112 }\end{array}$ & $\begin{array}{l}\text { ICN/JP and ACN/JP and } \\
\text { ISD/20010101->20013112 }\end{array}$ \\
\hline Japan & JP & $\begin{array}{l}\text { ICN/JP and } \\
\text { ISD/20060101- } \\
>20063112\end{array}$ & $\begin{array}{l}\text { ACN/JP andnot ICN/JP and } \\
\text { ISD/20060101->20063112 }\end{array}$ & $\begin{array}{l}\text { ICN/JP andnot ACN/JP and } \\
\text { ISD/20060101->20063112 }\end{array}$ & $\begin{array}{l}\text { ICN/JP and ACN/JP and } \\
\text { ISD/20060101->20063112 }\end{array}$ \\
\hline \multicolumn{6}{|c|}{$\begin{array}{l}\text { Search query code: ICN - Inventor country; ACN - Assignee country; ISD - Issue date; } \\
\text { Similar queries were made in respect of other countries by using codes for respective inventor countries, viz. Taiwan - TW, Republic of Korea-KR, China- } \\
\text { CN, Singapore- SG, India- IN, Malaysia- MY, Thailand- TH, Indonesia- ID, Vietnam- VN, Sri Lanka- LK, Pakistan- PK, Russia- RU, United King- } \\
\text { dom- GB, Australia- AU, Germany- DE, Israel- IL, Argentina- AR, Brazil- BR, Mexico- MX }\end{array}$} \\
\hline
\end{tabular}

The Indian case study has been presented to stress similar studies that need to be undertaken for other Asian countries.

\section{DATA AND METHODOLOGY}

The bibliographic information in a patent document may provide relevant information for the analysis of leveraging of technological competence of inventors from Asian and other countries. The names of the inventors in the team of inventors of a patent include the information about the country of the inventors. The international patent class to which a patent belongs indicates the technical area of the competence of the inventors. The data on assignees indicates the name of the firm or organization that owns the rights in the patents as well as the country of the firm or the organization.

The search was made in the patent database of the United States Patents Office (USPTO) from the web site www.uspto.gov to obtain relevant bibliographic data of patents. The database was selected due its being public domain and on-line accessibility. However, it may be possible to access data from other similar sources. The search was made in the database by using the search query as given in Table $\mathbf{1}$ below.

The search resulted in data on number of patents for select Asian and other countries, the details of which can be seen in Table 2 and Table $\mathbf{3}$, respectively. The bibliographic data of patents wherein at least one inventor is from India were examined in detail to assess the pattern of leveraging technological competence and to consider specific dimensions relating to the pattern of contributions of Indian inventors, ownership of such patents by foreign or Indian assignees, and the technical areas of contributions of Indian inventors for patents owned by foreign or Indian assignees.

\section{ANALYSIS, RESULTS AND INTERPRETATION OF FINDINGS}

Leveraging Technological Competences of Asian inventors

Table 2 gives the comparison of leveraging of technological competence of Asian inventors by foreign and na- tional assignees. From the Asian countries, the inventors from Japan, Taiwan, Republic of Korea, and Singapore contribute more to patents owned by their national firms or assignees in comparison to their contributions to the foreign assignees. Among the other countries, the inventors from Australia, Germany, and Israel contribute more to patents owned by their national firms or assignees in comparison to their contributions to the foreign assignees. In terms of leveraging technological competence of inventors from these countries, it implies that either the foreign firms do not find technological expertise relevant to their niche areas available or these are simply difficult to access in these countries. In contrast, the inventors from China, Malaysia, Thailand, and Indonesia contribute more to the foreign assignees. Among the other countries, the inventors from Russia, UK, Argentina, Brazil, and Mexico contribute more to the foreign assignees. It implies that the inventors from these countries either do not find national companies to fully exploit their technological expertise or the foreign firms provide much better opportunities than the national firms. The pattern is more or less similar in 2001 as well as 2006 with some exceptions e.g. Singapore wherein the share of national firms decreased during 2006.

In case of India, in 2001, inventors almost equally contributed to patents owned by national and foreign assignees while in 2006, they contributed to more patents owned by foreign assignees in comparison to those owned by national assignees. It implied that there is close competition between national and foreign firms in leveraging technological competences of inventors from India.

The next key question that needs to be addressed is how firms from Asian or other countries leverage or utilize the technological competence of inventors exclusively from other countries without involvement of inventors form their own countries? The analysis of data in Table $\mathbf{3}$ indicates that the firms from Japan, Taiwan, China, and Republic of Korea are better placed to have utilized technological competence of inventors exclusively from other countries, the share of such patents, however, varies from $2 \%$ to $11 \%$. The policies 
Table 2. Comparison of Leveraging of Technological Competence by Foreign and National Assignees (Data as Number of Patents)*

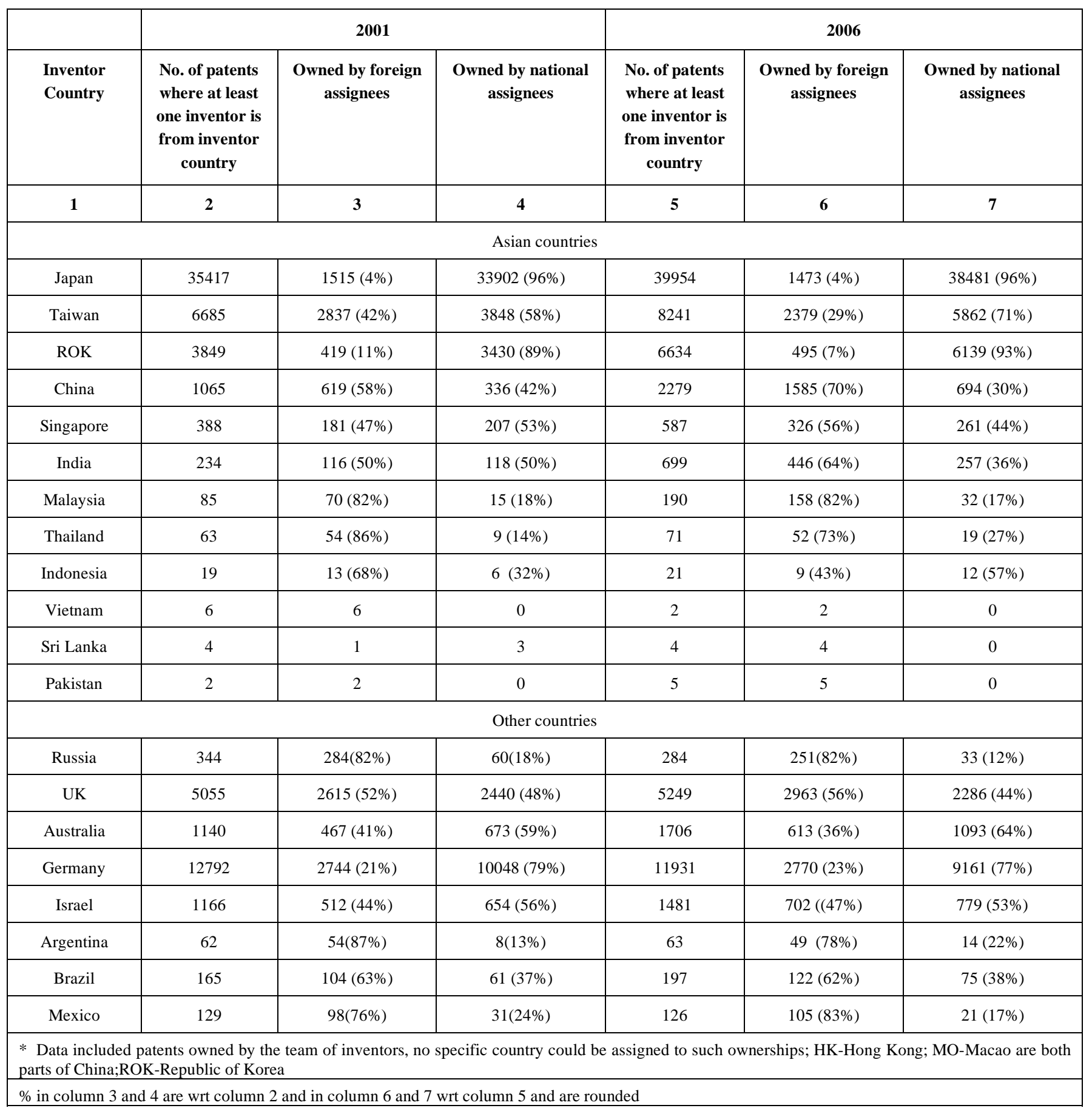

for innovation followed by Singapore over the period 2001 to 2006 have greatly enhanced its competence of utilizing technological competence of inventors from other countries in 2006 wherein the share of such patents reached to $40 \%$ in 2006. The firms from UK, Australia, Germany, and Israel extensively utilize the technological competence of inventors from other countries. Some of these countries like Israel, and Germany have improved the extent of such utilization from 2001 to 2006. This pattern clearly shows that firms are gradually enhancing their capacities to exploit talents for R\&D from other countries. The process of change appears to be in the initial stages and may become one of the central manifestations for firms' innovation strategies in future.

There is no significant presence of national firms in utilizing technological competence from other countries from countries like India, Malaysia, Thailand, Indonesia, Vietnam, Sri Lanka and Pakistan. Of the non-Asian countries, Russia, Argentina, and Brazil indicate that their firms do not adequately exploit the technological competence of inventors from other countries. The national policies for innovation in these countries require reorientation to encourage firms to reach out and enhance their capacities to make use of the 
Table 3. Leveraging Competence of Inventors from Countries Other than those of the Assignee (no. of Patents)

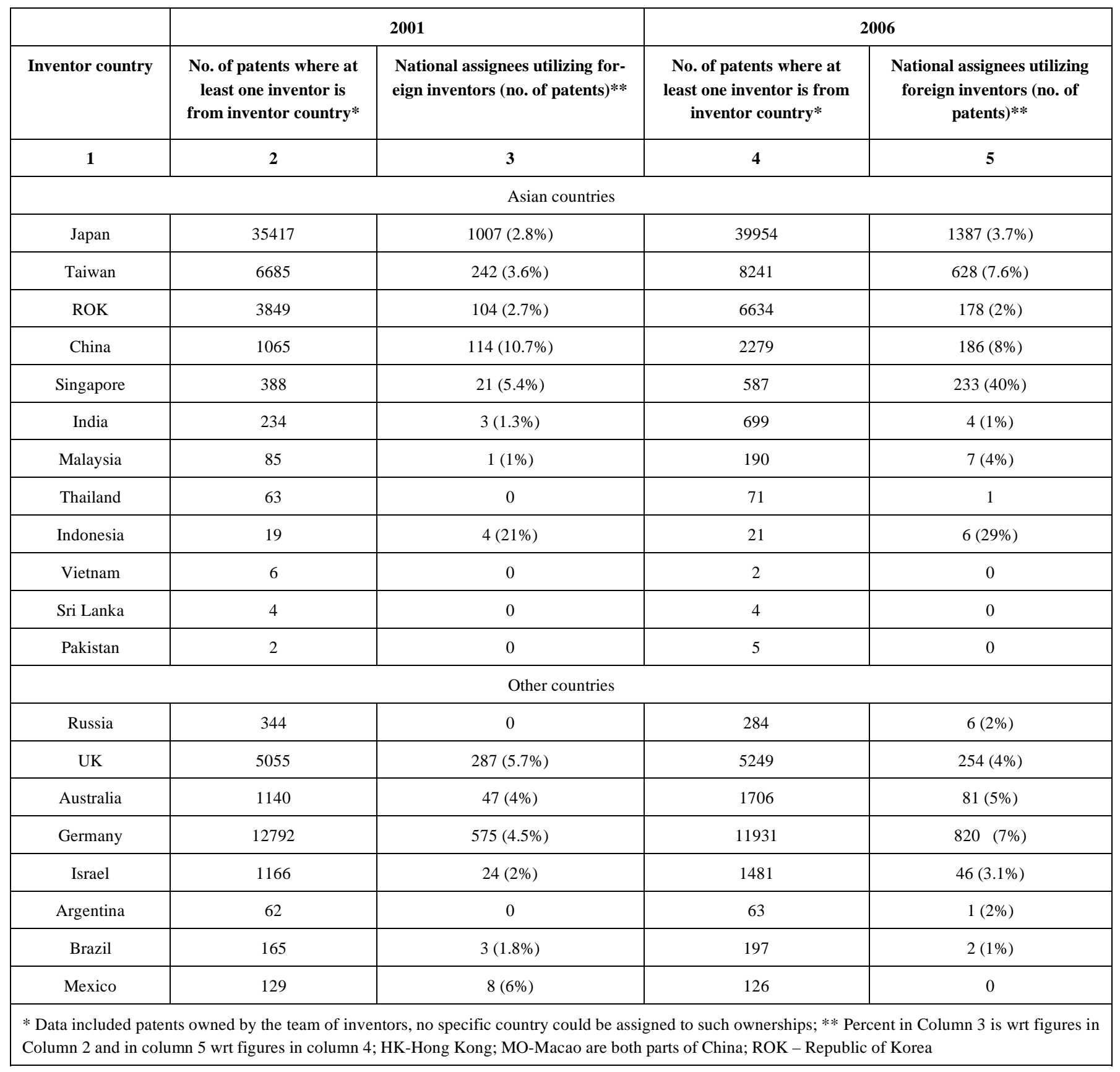

technological competence of inventors located worldwide, to retain their competitive edge.

\section{LEVERAGING TECHNOLOGICAL COMPETENCE OF INDIAN INVENTORS- A CASE STUDY}

The current emphasis of policy in India is to make her a hub of internationally competitive base for global outsourcing in knowledge intensive industries [1]. This opens up opportunities for foreign firms to utilize the competence of Indian inventors in a wide range of technological fields. The credibility of the technological competence of the Indian inventors is evident from their contribution to the global pool of scientific knowledge [2] and contributions to the global patenting activity [3]. The analysis of data in Table $\mathbf{2}$ indi- cates that, of the total 699 patents in 2006, the Indian inventors contribute more to patents owned by foreign assignees -413 patents $(59 \%$ of the total patents contributed by the Indian inventors) in comparison to 257 patents owned by Indian assignees ( $37 \%$ of the total patents contributed by the Indian inventors). There are 29 patents owned by the team of inventors in which case ownership has not been assigned to any specific country.

\section{Outsourcing by Foreign Assignees}

The analysis further indicates that in all, 1892 Indian inventors are involved in the contribution of total 699 patents. Of these, $828(44 \%)$ inventors contribute to the patents owned by assignees from foreign countries while 1014 
(54\%) inventors contribute to patents owned by Indian assignees. The Indian inventors contribute to patents owned by assignees from fourteen different countries. The maximum 384 patents are owned by assignees from USA and just 29 patents are owned by assignees from countries other than USA, which include Germany, Singapore, UK, Japan, France, Netherlands, Canada, New Caledonia, Malaysia, Macau, Israel, Switzerland, and Australia. Thus, the firms from United States utilize maximum number of Indian inventors. These Indian inventors participate as team member in patenting with almost equal number (863) of foreign inventors as team members. It is implied that in case of patents owned by foreign firms, the Indian inventors are often part of corporate research teams outside India or in the R\&D centers of such firms in India. By implication, the Indian inventors complement the ongoing R\&D efforts of the foreign firms.

In terms of number of inventors, more Indian inventors contribute to the Indian companies than those contribute to the foreign companies. There are only seven foreign inventors, which participate in the team of inventors of patents owned by Indian assignees, which may be the result of the formal international cooperation programmes between India and other countries. The insignificant participation of foreign inventors in patents owned by Indian assignees may reflect that the orientation of such collaboration may be more on basic research than applied or development research leading to patents.

\section{Outsourcing by Foreign Firms by Performing Sector}

The foreign assignees may belong to either of the performing sector, viz. industry, or university or government institutions. The industrial firms utilize maximum number, i.e. 799 Indian inventors who contribute maximum number of 392 patents owned by 113 foreign firms. Of these 90 firms are from USA and just 23 firms from other countries. In comparison, the contribution of Indian technological competence to $\mathrm{R} \& \mathrm{D}$ programmes involving foreign universities and government institutions is not significant.

\section{Foreign Firms Significantly Utilizing Indian Competence}

The General Electric Company (GEC), Texas Instruments and IBM Corporation have gained significantly by outsourcing Indian competence. GEC utilized 147 Indian inventors that associated with 162 foreign inventors in producing 59 patents. The Texas Instruments utilized 108 Indian inventors in association with 28 foreign inventors in producing 48 patents. IBM Corporation utilized the technological competence of 74 Indian inventors in association with 7 foreign inventors to obtain 31 patents. One significant feature of all these companies is that they have established R\&D centers in India. For example, the GEC's John F. Welch Technology Centre in India draws on India's unique multidisciplinary skills - from mechanical and electrical engineering to polymer science and chemical engineering. The Texas Instruments, a worldwide leader in semiconductors, set up an R\&D facility, which is primarily a design centre with frontline development in analog and digital chip design and applications software, library and software tools, microcontroller and signal processing technologies. IBM has also established a Software Innovation Center, and a Research Labora- tory in the country. These R\&D centers credibly utilize the technological competence of Indian inventors. The analysis is in conformity with the observation that the increasing share of ownership of patents by firms from different countries than the one of the inventors reflects that such companies may have research facilities in the country of inventors [4].

The other companies that have benefited from the technological competence of Indian inventors include ICT companies like Intel Corporation, Cisco Technologies, Sun Microsystems, Hewlett-Packard Development Co, Microsoft Corp, Genesis Microchip Inc. and Freescale Semiconductor Inc. Some of these companies like Intel, Cisco, Microsoft, and Freescale too have established R\&D centers in India and benefit from the competences of Indian inventors. There are two companies in the field of drugs and pharmaceuticals, namely, GE Medical System Global Technology Co, which is part of General Electric Company and Reddy US Therapeutics that have utilized contributions from Indian inventors. The former obtained 10 patents wherein 23 Indian inventors contributed while the later obtained 9 patents wherein 53 Indian inventors contributed including those from its Indian counterpart Dr Reddy's Laboratories.

Robert Bosch and Siemens Aktiengesellschaft from Germany, Thomson Licensing, France, Rolls-Royce PLC, UK, Fujitsu Limited and Toyota Jidosha Kabushiki Kaisha from Japan, and STMicroelectronics Asia Pacific (Pvt) Ltd from Singapore are companies from countries other than USA that have benefited from the talent of Indian inventors.

\section{Utilization of Indian Competence by Indian Firms and Organizations}

The pattern of utilization of Indian competence by Indian companies and other Indian organizations indicate that the government institutions maximally utilize such competence. The Council of Scientific and Industrial Research (CSIR) was the major government agency, which owned 123 patents wherein 572 Indian inventors were involved. There were 54 firms from the Indian industry that utilized the competence of 360 Indian inventors contributing 111 patents. There were several joint patents between government institutions, industry, and universities from India. Six patents were jointly held between CSIR and the Department of Biotechnology, Government of India. There were nine patents involving firms in the industry from India like Dr Reddy's Laboratories, L\&T Demag Plastics Machinery, and ST Microelectronics, which had joint patents with their foreign counterparts. There were three institutions from academia, viz. Indian Institute of Technology and Indian Statistical Institute, which had three joint patents with foreign firms, viz. Intel Corporation and Vitene Semiconductors Ltd from US.

The leading Indian firms that have gained from the competence of Indian inventors include Ranbaxy Laboratories Limited (49 inventors contributing 7 patents; Indian company in 2006 later taken over by Japanese company), DR Reddy's Lab Ltd (37 Indian inventors 10 patents), Wockhardt Limited (28 Indian inventors contributing 4 patents), ST Microelectronics (25 Indian inventors contributing 14 patents), Dabur Research Foundation (19 Indian inventors contributing 3 patents), Indian Oil Corporation Limited (19 
Indian inventors contributing 3 patents), Sun Pharmaceutical Industries Limited (13 Indian inventors contributing 4 patents), Cadila Healthcare Limited (12 Indian inventors contributing 3 patents), Lupin Labs Ltd (11 Indian inventors contributing 2 patents), Galaxy Surfactants Limited (10 Indian inventors contributing 3 patents), and Hetero Drugs Limited (10 Indian inventors contributing 2 patents).

\section{Technical Areas Leveraged By Foreign and Indian Firms}

The technological strengths of Indian inventors, reflected in patents in US owned by Indian R\&D organizations and firms during 1970s, were in the area of drugs and pharmaceuticals, synthetic resins and chemical compositions, composite materials, adhesive bonding and hydrocarbon technologies. In early 1990s, the patenting also emerged in other areas, viz. bioengineering, calculators, computers and data processing systems, information technology, electronics and optics [5]. In contrast, the technological strengths of the Indian inventors reflected in patents taken in India during 1976-2004 were chemical technologies, drugs and pharmaceuticals, building materials, ceramics and refractories, and microorganisms or enzymes and compositions thereof [6]. These observations indicated that the areas of technological strengths of Indian inventors both for patents, owned by Indian organizations and firms in India as well as in US, were more or less the same, viz. chemicals, drugs and pharmaceuticals, and microorganisms or enzymes and compositions thereof.

In contrast, the present analysis indicates that the outsourcing of the technological competence of the Indian inventors by the foreign firms is predominantly in the areas of electricity, electronics and information and communication technologies (551 Indian inventors contributing in 289 patents), followed by chemical technology (185 Indian inventors contributing in 71 patents), and drugs and pharmaceuticals (49 Indian inventors contributing in 31 patents).

The priority areas of the contributions of Indian inventors to Indian assignees are predominantly chemical technologies (407 Indian inventors contributing in 76 patents), drugs and pharmaceuticals (265 Indian inventors contributing in 53 patents), biotechnology and food (172 Indian inventors contributing in 39 patents), and electronic digital processing and information and communication technologies (54 Indian inventors contributing to 34 patents).

The interpretation of these findings is that the foreign and Indian firms follow a different set of priorities while drawing upon the inventors' expertise from India. The top priority area of outsourcing of Indian inventors by the foreign firms is electricity, electronics and information and communication technologies. The participation of Indian inventors in this area certainly got accelerated after the setting up of $R \& D$ centers in India by leading foreign firms like GEC, Texas Instruments, IBM, or Microsoft, and Intel. The Indian firms do not attach high priority to this area. Thus, there is no loss of availability of skilled expertise to the Indian companies in this area due to outsourcing by forejon companies. maceuticals is such that Indian firms extensively utilize the technological competence of Indian inventors. The foreign firms also draw upon the Indian expertise in this field. Similarly, the foreign firms significantly draw upon the Indian technological skills in the field of chemical technologies, wherein there is also a significant presence of Indian companies. The most patents in the field of chemical technologies and drugs and pharmaceuticals are also owned by the leading government scientific agency, i.e. CSIR. The competition may be advantageous to government $R \& D$ agencies like CSIR, which may enhance the opportunities of outsourcing of its expertise by both foreign and Indian firms. The utilization of technological competence in the areas of chemical technologies, and drugs and pharmaceuticals by foreign and Indian firms is competitively placed. The Indian policy makers, however, would need to take appropriate measures to ensure that the competition in outsourcing of Indian technological competences in fields like chemicals, and drugs and pharmaceuticals does not harm the interests of the Indian firms.

\section{CONCLUSIONS}

The study indicates that the contribution of inventors from Japan and Republic of Korea to patents owned by foreign assignees is minimal while the contribution of inventors from Russia to foreign assignees is maximum. In contrast, the technological competence of inventors from countries like China, India, Malaysia, Thailand, Indonesia, Vietnam, Sri Lanka, and Pakistan is being utilized more by foreign firms than by respective national firms. In case of India, in 2001 , inventors almost equally contributed to patents owned by national and foreign assignees while in 2006, they contributed to more patents owned by foreign assignees in comparison to those owned by national assignees.

How firms from Asian countries leverage or utilize the technological competence of inventors from other countries than their own? The firms from Japan, Taiwan, China, and Republic of Korea have modestly utilized technological competence of inventors exclusively from other countries. The policies for innovation followed by Singapore over the period 2001 to 2006 have greatly enhanced its competence of utilizing technological competence of inventors from other countries. The firms from countries like India, Malaysia, Thailand, Indonesia, Vietnam, Sri Lanka and Pakistan do not utilize technological competence of inventors from other countries in any significant manner. The national policies for innovation in these countries require reorientation to encourage firms to reach out and enhance their capacities to make use of the technological competence of inventors located worldwide, to retain their competitive edge. It would be desirable for Asian developing countries to evolve a policy to selectively enhance their innovative capacity by outsourcing talent from other countries, which would also be in commensurate with emerging global context and competition.

The foreign companies, with $R \& D$ centers in India have gained significantly from outsourcing of the Indian competence. The outsourcing of the technological competence of the Indian inventors by the foreign firms is predominantly in the area of electricity, electronics and information and communication technologies, followed by chemicals and drugs and pharmaceuticals. The Indian firms do not attach high 
priority to the area of electricity, electronics and information and communication technologies. The utilization of technological competence in the areas of chemical technologies, and drugs and pharmaceuticals by foreign and Indian firms is competitively placed. The most patents in these fields are owned by the government R\&D agency, viz. CSIR, the competition may be advantageous to enhance its visibility for outsourcing of its expertise by both foreign and Indian firms. The Indian policy makers, however, would need to take appropriate measures to ensure that the competition in outsourcing of Indian technological competences in fields like chemicals, and drugs and pharmaceuticals does not harm the interests of the Indian firms. For this purpose, the Indian companies would need to be encouraged to outsource the talent of inventors from other countries, on the one hand while on the other, new centers of excellence in science and technology for higher education may be created to enhance the supply of requisite scientific and technological manpower.

In view of the Government of India following an open policy to encourage outsourcing of Indian competence in the knowledge based industries, it will be desirable to continue to encourage the foreign firms to establish $R \& D$ centers in the country, and vice versa, the foreign companies to take initiatives to benefit from the wide-range of Indian technological competence by opening up $R \& D$ centers in India. The study recommends that the Indian companies need to evolve strategy for more effective collaboration in R\&D with other countries as well as to outsource talent from other countries or set up R\&D centers in other countries so as to enhance their innovative capacity.

\section{FUTURE WORK}

The Indian case study indicates significant features of the analysis that can throw light on the outsourcing of scarce talent by national or foreign firms. No such analysis is available for other Asian developing countries. For this purpose, it is necessary that further work is undertaken for a deeper analysis of how inventive talent from these countries is being utilized, by whom and in which technological areas. The socio-economic and political contexts of each of these countries vary where similar analysis might help in the formulation of appropriate innovation policy and strategies at the national or firms' level relevant to their respective policy contexts. The author will be willing to collaborate in planning and implementing such studies with institutions from these countries.

\section{REFERENCES}

[1] Foreword by Rangarajan C. Nagesh K. Joseph KJ, Eds. International competitiveness \& knowledge-based industries in India. New Delhi: Research and Information System for Developing Countries, Oxford University Press 2007.

[2] Gupta BM, Dhawan SM. Measures of progress of science in Indiaan anlysis of the publication output in science and technology. New Delhi: Office of the Principal Scientific Adviser to the Government of India 2006; Report No.: PSA/2006/4.

[3] Gupta VK. How Indian scientists collaborate in patenting? Ann Libr Info Stud 2005; 52(2): 47-50

[4] Cincera M, van Pottelsberghe de la Potterie B, Reinhilde V. Assessing the foreign control of production of technology: the case of a small open economy. Scientometrics 2006; 66 (3): 493-512.

[5] Gupta VK. Trends in post WTO patenting by India in US. Curr Sci 2000; 78(8): 955-9.

[6] Gupta VK. Evolution of technical competence in CSIR: a case study using patents data. Desidoc Bull Info Technol 2007; 27(1): 77-86. 